Filosofia Theoretica: Journal of African Philosophy, Culture and Religions

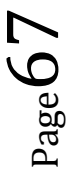




\title{
FROM MAGIC TO AFRICAN EXPERIMENTAL SCIENCE: TOWARD A NEW PARADIGM \\ DOI: http://dx.doi.org/10.4314/ft.v4i2.5
}

\author{
Christian C. EMEDOLU, PhD \\ Department of Philosophy, University of Port Harcourt, Nigeria
}

\begin{abstract}
This paper assumes that there is a distinction between empirical and non-empirical science. It also assumes that empirical science has two complementary parts, namely, theorization and experimentation. The paper focuses strictly on the experimental aspect of science. It is a call for reformation in African experimental science. Following a deep historical understanding of the revolution that brought about experimental philosophy (as modern empirical science was called up to the time of Newton) this paper admits that magic was the mother, not just the "bastard sister" of empirical science. It uncovers the fact that magic added the dimension of experimentation to science. This paper somewhat maintains that most of the ideas presented by some African scholars contain vestiges of the magical tradition in them. Even though this might not be a flaw by any reasonable standard, the paper still argues that there is a genuine need to separate magic from science, if we ever crave for any form of material/physical progress in Africa. I insist that the thrust of the call for paradigm shift in this paper is centered basically on experimentation. The issue of theoretical entities was introduced only to the extent such entities enhance experimental realism in the practice of African science. Of course, reformation can equally take place at the level of scientific theorization, but that is strictly beyond the scope of this paper. The fact is that those who are versed on the issues of experimentation should begin to get more focused on that aspect; and those who are given to theorization should settle with the formulation of well-structured theories. Time has indeed come for us to properly streamline our thoughts and make progress in the direction of African experimental science. In making this clarion call, we adopted a combined approach of hermeneutics and analysis.
\end{abstract}

Keywords: Magic, African science, experimental science, paradigm, African thought

\section{Introduction}

Many anthropological and ethnographical studies have been done on the African continent. But such studies stop short at the level of theoretical descriptions and historical documentations of African worldviews: past and present. Perhaps time has come for African philosophers and scientists to provide the necessary framework for the ultimate emergence and take-off of a modernized African experimental science ${ }_{\overparen{C}}^{\infty}$ constructively modeled on instrumental manipulation of entities. Ars Magica Africana (African magic) must be re-examined to ascertain the possibility of any smooth or robust reform. Magicians are often seen as those who ply their trade by 
playing tricks. "The more you look the less you see" is the home truth about those tricksters. This is a very naïve sense of magic which cannot be applied to what we shall espouse in this paper. Magic, basically, has several forms, ranging from sympathetic to contagious magic, and a lot more. Generally speaking, magic, from its inception, was a serious practice that is housed within the technical or craft tradition (in contradistinction with the theoretical or scholarly tradition). Much as there are so many interpretations and misunderstandings of magic, we do not just wish, at least, to see magic from the anthropological threshold of the "...distinctive mentality of "primitive" (WIENER 2004, 10). I have long convinced myself that magic is forever dynamic and keeps on updating itself; for as Barbara A. Strassberg writes: "Magic, religion, science, technology, and ethics are components of cultures that coexist at every stage of the evolution of societies and cultures..." $(2005,307)$

Bearing this in mind, the paper will begin by exploring the initial question of the possibility of African science, wherein the efforts of other scholars of African progeny are duly acknowledged. It will examine some misconceptions regarding magic and witchcraft - with witchcraft, of course, serving only as a special grade of magic. From there this paper will move into the contemplation of the idea of methodological reformation. Thereafter, it will run into the question of availability of entities for the purposes of constructing relevant experimental instruments with the attendant objective of manipulating such entities. With such a modest proposal, there is no doubt that the actual beginning of experimental science in and for Africa will usher in a season of gradual end to Africa's crisis of self-identity. This Euromotivated crisis has made Africans feel hollow on the inside, and they have imbibed the belief that nothing good can come out of their own original system of navigating the world. Diabolism has remained the unsung myth of all African cultures. Now, let us start with the possibility of possessing a de-charlatanized and de-diabolized conception of the African.

\section{On the Possibility of African Science}

There is a dialectical dimension to the pattern of raising questions regarding the possibility of existence of any discipline. For instance, in the fifth paragraph of his [Prolegomena to Any Future Metaphysics], Kant raised the following pertinent issue: "To ask, therefore, if a science is a possibility, presupposes a doubt that the science exists in actuality". In spite of this, Kant himself went ahead to pose questions regarding the possibility of metaphysics as a science and metaphysics as a natural disposition. Fortunately, there was metaphysics, before Kant posited his own questions, even though he regarded metaphysics as a sure tempest, an abysmal ( $A b$ grund) ocean without shore lines. But intrinsically, Kant merely wanted to navigate and dredge up some reformative formulae for putting metaphysics on the highway of Oprogress, so to place modern metaphysics on the same pedestal with the physical osciences. In other words, putting forward a question remains a matter of flatus voce

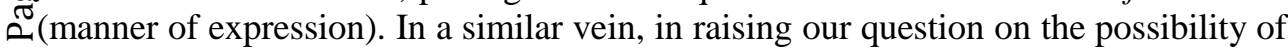
African science, we are ultimately craving that the science Africans currently possess 
be made orderly (more systematic) and self-corrective in its quest to exploit, understand, predict, manipulate and dominate nature.

Given the fact that African philosophy eventually carved out a niche for itself after the wrangling of the Great Debate, one may seem to see it as the shortest step to the acceptance of any proposal for the existence of African experimental science. But not many scholars will accept such a proposal without a fight or argument. When I first muted the idea of standardization of African experimental science (in 2006) on the occasion of a departmental mock viva preceding my actual doctoral defence on Ian Hacking's Experimental Realism, I was practically bullied by three quarters of the professors and lecturers present. I was intimidated into expunging the idea from my Thesis for lack of merit. Most members of that panel held this idea that science is universal. Of course, under such a crucible I was quite aware of the orthodox picture presented by Alfred North Whitehead namely, that "Modern science was born in Europe, but its home is the whole world" $(1948,5)$.

One of the panelists particularly showed a more complete disavowal of the notion of African science. According to him, nothing can make any scientific idea African. Pretty clearly, Okere (1983) had for more than three decades ago pointed out that it is quite difficult to map out criteria for discovering "something specifically black African" in the area of natural sciences. In short, Okere's very words run thus: "In the area of the natural sciences, finding out decisive criteria might prove elusive than in the case of the arts or the human sciences" (vii). But, then, in a work Okere published more than two decades afterwards, he insists that: "The notion that there is only one science, western science, is pure dogma, a dogmatic belief supported by purely ideological positions, some stated, others not". It is the case for Okere, therefore, that there is African science - though it may not be on the same level with western science - just in the same manner we have African music, literature, art, and so on. $(2005,158-160)$.

Consequent upon this Okerean position, the member of the panel was partly right. $\mathrm{He}$ was right in a somewhat slightly naïve sense. In the third chapter of [Emergent and Contentious Issues in African Philosophy, 2004], Boniface Nwigwe and Christian Emedolu laboured over what can make any philosophical idea African. They examined the views of both Universalists and non-universalists alike. Paulin Hountondji, Emmanuel Eze, T. U. Nwala, Olabiyi Yai, B. C. Okolo, Barry Hallen, Theophilus Okere, Francis Ogumodede, Damian Opata, and Odera Oruka were among those whose views on the issue were considered. Kwasi Wiredu and Campbell S. Momoh can also be veritable mines of information on this issue. Be that as it may, Nwigwe and Emedolu ultimately discovered that nothing can actually make any idea whatsoever essentially African. The unsung thrust of their argument ultimately is that humanity is one, irrespective of any false ideology of race or what $N_{y}$ you will. It is even more implicating to argue from the point of view of culture; for DoAfricans do not have a unified cultural orientation both in their material and immaterial cultures. In any case, Nwigwe and Emedolu tried to invoke the hypothesis of existence of a metaphysical link among African cultures. This metaphysical union 
arises in the manner of Dudley Shapere's thought, namely that "...what is visible exhibits differences, what unites those things must be invisible" (SHAPERE 1981, 58). In spite of these difficulties, Damian Opata has tried in his essay, "On What is African", to isolate four different conceptions of the term "African". He sees it simply as geographical, racial/ethnic, ideological and epistemic term (OPATA 1992, 61-80). They are undoubtedly some ways of conceiving the term African. I tend to see the term from both geographical and racial or cultural points of view. This ties in well with Uduma O. Uduma's position that a philosophy becomes African by virtue of having at once a geographical content and cultural content (UDUMA 2014, 143). It also tallies somewhat with David A. Oyedola's position which stipulates that, in searching for what is African "we have to look for a synthesis of which the author and the issues discussed in a work must reflect the discussion of problems relating to African conditions" (OYEDOLA 2015, 70). As Chimakonam rightly says, "we cannot possibly move forward without" having the issue of Africanness properly resolved (CHIMAKONAM 2015, 48).

The problem with the debate on the Africanness of a philosophy or of a science is that it often remains at the level of transcendence or a priori hair-splitting. But no matter how abstract its mathematical schema or hypotheses may be, modern empirical science remains a scientia media - i.e., that which stands mid-way between philosophical physics and mathematics in the order of Aristotelian degrees of abstraction. But whatever else it may mean, what is African, for us, can only be derived under the conditions of division of intellectual, geographical and cultural labour.

As it stands, I accept the definition of African science given by Godfrey Ozumba. He simply sees it as the "African man's way of observing, systematizing, testing, and confirming facts of his environment, with the aim of achieving a high level of understanding of his environment to aid him in controlling or manipulating the forces of nature to his advantage..."(OZUMBA 2000, 20). Now, such a view brings out the pragmatic character of scientific knowledge to the extent that it helps us gain control over nature by assisting us in the manipulation of "the forces of nature" to our advantage. The goal of science is not merely to describe or explain things within our environment, nor is it only to assist us in making predictions and navigating our way through nature; but science, like magic, helps us to exploit and dominate nature. This ambition of the scientific enterprise was clearly seen by both René Descartes and Francis Bacon in their shaping of the mechanistic worldview of science in the early modern period.

Innocent Asouzu did mention that, the reason some scholars "who work on the project of systematizing African science try to strike off the metaphysical is - because African scientific experience in its original form is couched in, or anchored Non the mythico-religious method..." (CHIMAKONAM 2012 a , 35). I do agree with ס્Chimakonam that, "A science which does not include the metaphysical in its map of

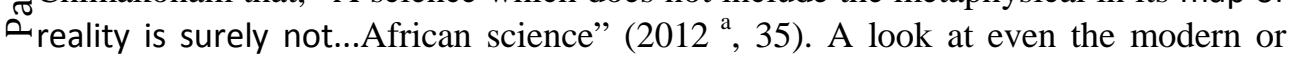
Western science shows that there is no flight away from metaphysics, despite the 
attempts made by the logical positivists to eliminate metaphysics. Science must be built upon some metaphysical foundations. Rom Harré highlights even how some metaphysical concepts have crept into discussions in science. These conceptual problems include "how our thing-concepts are related to our space-concepts"; "whether our concept of temporal direction is contingently or necessarily connected with our concept of causality" and so forth. Hence, Harré summarily writes: "in recent years some of these conceptual problems and studies have moved into the foreground of science. Discussions of problems about the concept of causality and the concept of thing-hood have appeared in physics, particularly in commentary upon attempts to interpret quantum mechanics in a useful and consistent way" $(1985,9)$. From the foregoing, therefore, it will be quite unreasonable for anyone to attempt to expunge or divorce metaphysics from science. The fear of metaphysics is, incidentally, part of what makes "...some Western trained Africans scholars ... fall into the error of supposing that whatever that must qualify as science must take a full empiricist dive" (CHIMAKONAM 2012 a 35). But the truth is that anybody who falls into such a silly error is not worth his onion and should withdraw from any legitimate discussion on the nature and history of modern empirical science. One who has a fair idea of the battle between Newton and the Cartesians, wherein Newton made the famous dictum "I feign no hypotheses", would grasp the eternal truth that science, in its theorizations, goes beyond the empirical. Moreover, one who has a good knowledge of the problem of underdetermination of scientific theory by empirical or experimental data raised in 1600 by Christopher Clavius, should rightly infer that there is no categorical equivalence or isomorphism between any theory and the empirical data linked to it (EMEDOLU 2007 $\left.{ }^{\mathrm{a}}, 46\right)$. Clavius, ultimately, maintains that theories should be judged not only for their fit to the observed or experimentally established facts, but also for their plausibility as descriptions of real but unobservable processes that cause the phenomena we observe (HARRÉ 1981, 10).

Where I seem to disagree with Chimakonam is on the point that "African science approaches nature with equanimity, like a man approaching a maiden he wishes to marry, curious but gentle" $\left(2012^{\mathrm{a}}, 35\right)$. I share the vision of Bacon, who stipulates that in matters of experimentation, the "lion's tail" must be twisted, and the "folds of nature" must be shaken out (HACKING 1983, 246). In matters of experiment one often needs to do some violence in order to fast-track the process. The gentle hermitic experimentalist did not achieve much by sitting patiently, waiting for nature to unfold herself. Even if we take nature as a biological organism, following Aristotle, Henri Bergson or Alfred North whitehead, she still requires the hammer and the chisel of the mechanist to be completely exfoliated. Therefore, African scientists should not be afraid of exploiting nature, even at the cost of being Nconsidered as "un-gentle", so long as they achieve results that can be of immense Nonefit to mankind. 


\section{Misconceptions about African Magic (à la interpretatio Greca)}

One area from where the mock Ph.D defense panel tried to debunk the idea of African science is magic or witchcraft. They argued that Africans may have their witchcraft and or magical practices, but that does not mean we must grant some such practices scientific status. Furthermore, they argued that the witchcraft phenomenon and all forms of magic were practiced in Europe in both medieval and modern periods. In other words, they seemed to believe that science has always dissociated itself from such occult and mystical practices. But, then, the history of science does not actually teach that. Magic, in European tradition was indeed the very "...matrix of a truly scientific experimentation" (MCNEILL 1935, 344). In "Magic and Origins of Modern Science", John Henry clearly confirms that, "Without the tradition of European magic, science and scientific medicine could hardly have developed as successfully as they have.... So history reveals that modern science was able to make such rapid gains in the $17^{\text {th }}$ century only by plundering natural magic" $(1999,1)$. Magic, as it were, paved the road for modern empirical science.

Obviously, the two concepts, science and magic, were kept apart only in later modern thinking. The logic is that while science gradually increased, magic rapidly diminished until interest in it faded in the wake of the 19th century. Paul Feyerabend affords this outstanding revelation that science uses ideological means to take from other forms of life (especially, witchcraft and other forms of magic) and increased itself; by so doing science tends to inflict redundancy on other forms of life (FEYERABEND 1981, 156-166). This ideological drama will be better unfolded as we proceed. But there is no getting away from magic. Contemporary science still retains some magical charms as much as the modern science did. To an innocent mind scientific experiment, even as we know it today, is as magical as ever. It essentially stops holding its magical fancy when we rationalize and understand the technical implications of its design. This goes to corroborate what Aristotle said, in [Metaphysics] (Bk 1, Ch 2, $983 \mathrm{a}^{15}$ ), more than two thousand years ago: "For all men begin... by wondering that things are as they are... for it seems wonderful to all who have not yet seen the reason". There is no gainsaying the fact that such practice as magic (having witchcraft as one of its forms) has always been part and parcel of science and technology right from Egyptian antiquity up to the dawn of $21^{\text {st }}$ century. One who understands the history of science should know that modern empirical science is a rational enterprise that has grown into manhood and has seemingly severed its umbilical cord or placenta from magic, but still retaining a protruding navel as a sign of that dignified connection with its mother, magic.

Henceforth, a little historiography makes the foregoing claim very clear to us. One of the foremost Egyptologists of our time, Martin Bernal, explains how much Mmodern European empirical science is indebted to African or Egyptian science of

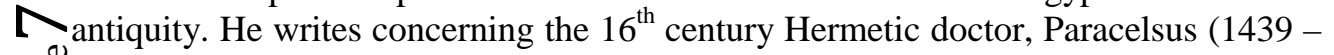
ర్م01541), thus: 
He [Paracelsus] was only near the beginning of a tradition which continued up to and included Newton, in which scientists justified turning to experiment as a way to retrieve the wisdom of Egypt and the orient which the Greeks and Romans had failed to preserve. (BERNAL 1991, 157)

The Egyptian Hermetic texts contained what Bernal describes as prisca theologia and prisca sapientia - which are primordial and autochthonous religious (or theological) thoughts, magic and general wisdom concerning reality. In other words, most of those Hermetic texts were mainly books of magic, i.e., books on how to master and subdue nature. A few happy Renaissance thinkers of Europe were so fascinated by some of these legendary and important texts and made some incursions into them. In this manner modern western science was able to make its mark from the debris of African science of antiquity - call it magic or what you will. Precisely speaking, in the context of Egyptian antiquity, George G. M. James explains it thus: "It must ... be noted that magic was applied religion or primitive scientific method" $(1954,134)$. This goes to refute what Karl Popper said, namely that primitive science began in the wake of Ionian school of philosophy in ancient Greece. Popper's exact words run as follows: "The first beginnings of the evolution of something like a scientific method may be found, approximately at the turn of the sixth and fifth centuries B.C., in ancient Greece" $(1972,347)$. This Popperian view certainly depicts one who is heavy with Eurocentric model of history. But we must go with the Ancient model, which holds that wisdom and learning belonged to the Egyptian priest-philosophers three to four millennia before the emergence of the Greeks. Concerning Egyptian origin of modern science, T. U. Nwala declares:

Alexandrian Academy [in Egypt] was the intellectual centre of the world between 300 B.C. and 400 A.D. What is called Greek Science from 300 B.C. . . was indeed Alexandrian science. The Alexandrian Academy hosted some of the most eminent philosopher-scientists who laid the foundation of modern science and philosophy. $(1972,10)$

In my book, [A Concise History of Scientific Experiment], I went beyond the Alexandrian period in tracing the link between magic and scientific experiment. But it is the case that we still currently see something scientific and empirical in the socalled African witchcraft and black magic - if the appellation "Black" is fit and apposite here. In African magic, which Popper might classify as a pseudo-science, there is always an embedded principle of creation of phenomena - i.e., " $K$ 'ihe emere n'ere" (Let that which is performed be effective). "K'ihe emere n'ere" forever remains the landmark and pitch of every successful experimental demonstration. A clear understanding of African magic ties in well with the definition given in Dennis DDiderot and D'Alembert's [Encyclopedia] (1751-1772), wherein magic is seen as an ळoccult science or art that teaches how to do things which seem beyond human ¿power" (BAUDSCH 1939, 441). This leads me to insist with Bronislaw Malinowski 
that, "...in the magical act the underlying idea and aim is always clear, straightforward, and definite" (COOK 1983, 14).

African magic is not always about spirit entities and demons, as in the case where St. Thomas Aquinas warns against the inordinate and unlawful acquisition of knowledge of "...the future through the demons"; for some such truths are "...above the capacity of (man's) own intelligence" [Summa Theologiae] (IIa, IIae, Q167, Art. 1c). Inability to distinguish between a thoroughgoing demonic magic and natural magic (pure and simple) was sometime very prevalent in Europe. Perhaps, Frankensteinian witchcraft and White magic could be so dangerous as to warrant the burning of witches at the stake. Even at that, the supposedly free and scientific minds were not spared either. Giordano Bruno was burnt at the stake in 1600, and Galileo suffered the inquisition in the 1630s until his death in 1642. All this could be attributed to ideological exigencies of those precarious moments in Europe.

Now, in trying to refute the panel's claim that we cannot associate or link some of the features of African magic and witchcraft with science, we must also bring to the fore the comparative study done by Robin Horton in [Patterns of Thought in Africa and the West: Essays on Magic, Religion and Science]. He juxtaposed African witchcraft and magic with Western science. Incidentally, from Horton's study, African science is always that primitive counterpart whose similitude to Western science is dimly or never perceived at all. To my mind, what lies at the root of all this is more or less pure misinterpretation or common demonization of everything that is African. The claim bandied by James Frazer that, "...magic is a spurious system of natural law as well as a fallacious guide of conduct" is quite contentious. Frazer even goes further to conclude that magic is never a science, or that it is "a false science", and that "it is always an art" or "an abortive art" (1993, 11). Modern empirical science is often called "experimental science" mainly to commemorate the union between natural magic (initiator of experiment) and Greek theoretical knowledge (harbinger of science/historielepisteme). But we must ask ourselves, again and again, what science is. Whatever else it might be, knowledge must be within the kernel of every just and sincere definition of science. It can be knowledge of reality, principles or any other thing. Science has commonly been seen as a demonstrable, organized and systematized knowledge about reality. Whereas the concept of organization or systematization is clear, that of demonstrability is somewhat vague. The reason is simple: the idea of demonstration in Aristotelian and medieval science has to do with pure a priori and logical validation of knowledge; but in our time it has to do somewhat with observational and or experimental validation of theory or knowledge $\mathbf{\Omega}$ - as such, experimental demonstration becomes the warrant for asserting any $\checkmark$ theoretical belief. As such, in modern empirical science, sensory knowledge odknowledge at the level of doxa - has ultimately become the very key to technological $\tau_{\text {transformation of the physical world. This could provide a whiff of the primordial }}$ legacy of magic. 
In essence, African witchcraft and magic constitute, in their own right, a body of knowledge and practice properly organized. Fortunately, this forms one of the crucial steps leading to the establishment of similitude and connectivity between African science and that of the West. After all, Imre Lakatos did not mince words in revealing that, "Glanvill, the house philosopher of the early Royal Society, regarded witchcraft as the paradigm of experimental reasoning" (LAKATOS 1980, 3). A look through the early papers and investigations of the members of the Invisible College (later dubbed Royal Society of London) showcases a thick whiff of Hermetic magic and witchcraft. The body of knowledge contained in African magic is a full-fledged paradigm (in the sense of worldview). The question now is: How do we transform this paradigm to suite or approximate any authentic and acceptable Western scientific (theoretical/experimental) paradigm? Yet an argument may be raised that if we pattern our dream experimental science this way, then it ceases to be African. On the contrary, it might not be the case that it will cease to be authentically African. In this regard, Larry Laudan presents us with what he calls the reticulate model of paradigm switch/shift. He loudly maintains that there are three basic elements of a paradigm, which include ontology, methodology and values (CASTELL 1994, 656). In the course of a major paradigm shift, two of the elements might change, and only one would remain. As Laudan writes:

Changes in values and changes in substantive ontology or methodologies show no net isomorphism, change certainly occurs at all levels, and sometimes changes are concurrent, but there is no striking covariance between the timing of changes at one level and the timing of those at any other. (CASTELL 1994 660)

Of course, Thomas S. Kuhn left us with a legacy of about twenty-two different meanings of "paradigm". In some senses paradigm could be seen as a set of shared values, achievements, methods and so on. But the sense we are concerned with presently is paradigm as a worldview. By calling forth a Kuhnian kind of revolution, we do not wish to be associated with his notion of Gestalt Switch, which conceives Scientific Revolution in pure terms of religious conversion - with its bandwagon effect. Ours is a revolution where anyone joins in the full blaze of Reason.

Values and ontologies aside, we have to look critically at the issue of methodology in what follows. This is precisely the case because it is from re-thinking its methodology that African science or knowledge will now begin to actually assume the dimensions of exact formulation, description, and predictability. This somewhat corroborates Popper's position which stipulates that, “...science must begin... with the critical discussion of myths, and of magical techniques and Opractices" (EMEDOLU 2013, 235). Yet, this does not imply that, in what follows, Neverything that is African in our magical tradition must be changed. 


\section{On Reformation of Method in African Science}

One modest truth which is yet to sink into the minds of most scholars is the fact that scientific knowledge is not essentially different from any other kind of knowledge. Knowledge is nothing but belief backed by faith, reason and experience. Some philosophers in the ranks of John Dewey and Michael Dummet will categorically say that knowledge is warranted assertability or justified true belief. Whatever else human knowledge may entail, it does not, for our present purposes, include any sense of the absolute and perfect rationality. To insist on absolute knowledge is to veer off to the realm of Primum mobile, Actus Purus or Supreme Being. Such apokrisis (separating-off) between the divine and the human must be taken cognizance of; hence we must go with John Locke, David Hume, Immanuel Kant and Ludwig Wittgenstein to admit that human mind must know its limits and keep to those limits.

Before we can engage in any meaningful discussion on the issue of method in science, we must understand the fact that there are different modes of being. As Lawrence Leshan writes:

We do know of four and something of the basic nature of each of these. I will term these the sensory modes of being, the clairvoyant modes of being, the transpsychic modes of being, and the mythic modes of being. $(1976,47)$

It is important to note that these modes are not watertight ontological compartments. Individuals can crisscross them at will. But the empirical science we discuss in the present context is one that operates within the sensory modes of being, wherein knowledge is very discursive or amenable to empirical analysis. To deduce from the foregoing that Western scientists do not accept other forms of life is to plunge oneself into the fallacy of ad ignorantiam. Morris Cohen and Ernest Nagel insist that scientific method knows its limits, and as such, "it is an error to suppose, as is often done, that science denies the truth of all unverified propositions $(1992,481)$. Paul Feyerabend equally assures us "... that science is never a closed system of knowledge" (EMEDOLU \& ONUOHA 2007, 62). Science keeps learning from other forms of life; for instance, when Chinese traditional medicine was introduced into the universities during the Chinese Cultural Revolution, "Chinese science advanced and Western science learned from it" (FEYERABEND 1981, 162).

Feyerabend's dadaism ("anything goes" philosophy), which works on the basis of J.S. Mill's "proliferation principle", is targeted at puncturing "methodologism" in science. The excessive crave for method has been aptly regarded as "scientism", and John Marks defines it as "... a tendency to extend, the methods or results of science to areas in which application or relevance is doubtful" $(1983,247)$.

The fact that method is the "touch stone" of science is very evident in what Beverly Halstead's says:

Quite often when relaxed, not thinking of anything, the answer suddenly pops into one's head... Such a process will not be described in scientific papers. If I 
had tried to publish this idea in the way it happened, the editor would have rejected it. It would never be published because that is not the 'scientific method'. $(1974,89)$

To be sure, René Descartes, in the modern period, used a story to drive home the urgency of method in scientific investigation. His very words run thus. "As well might a man burning with an unintelligent desire to find treasure continuously roam the streets, seeking to find something that a passerby might have chanced to drop.... It were far better never to think of investigating truth at all, than to do so without a method" (EMEDOLU 2009, 65).

This launches us, then, into what some scholars regard as methods in African experimental science. In his "Towards a Theory of African Science: Methods and Justification", Okeke Jonathan Chimakonam outlines "Ako-nwalee" (Trial and error), "Ako-iju-ase" (Interscience), "Ako-ime-obi” (Introscience), "Ako-nyirionwe" (Semscience), and "Ako-nso-n'azu" as some of the vital methods in African science (2012 a, pp.36-39). All of them are central to the hermetic tradition of science. The trial and error ("Ako-nwalee") approach is one of the earliest traditions of scientific experiment. Of course, there are other later traditions of experiment, which we shall see later in this section. "Ako-ime-obi" is also very pivotal in all disciplines. Without it one cannot even begin to contemplate any experimental design. "Ako-iju-ase" is a pure approach in demonic magic which can also be applied in western science. But the most important thing is that after gaining any insightful knowledge, one must have to reconstruct a logical and empirical footpath to such knowledge (or secret gnosis) by way of logic of justification. "Ako-nyiri onwe", for its part, is a vital residue of the experimental approach to science. Lastly, "Ako-nson'azu" is central to modern empirical science, despite the logical positivists' endeavour in trying to downplay explanation in science. Philosophers of scientific experiment like Ian Hacking and Nancy Cartwright did discuss causality within the domain of experimentation, using the phrase "inference to the best causal explanation" (IBCE). But we must emphasize that causation is better conceived as a form of explanation in science. Beyond causal explanation, there are other forms of explanation, such as functional explanation, model explanation, systematic explanation and teleological explanation (EMEDOLU 2010, 70-83).

In the philosophy of science, generally, most scholars tend to run the quartet concepts of technique, method, process and procedure together (EMEDOLU 2007, 17). It is even more worrisome in the discourse domain of scientific methodology. Hence, Imre Lakatos writes: "there are several methodologies afloat in contemporary philosophy of science; but they are all very different from what used to be Ounderstood by 'methodology' in the seventeenth or even eighteenth century" (1981, 108). It is in this light that Feyerabend observes that, "Lakatos criticizes the existent Ð̊methodologies..." (1978, 182). But despite the fact that Lakatos erected the edifice of ${ }^{\top}$ his own methodology of scientific research programmes upon the foundations of Karl Popper's Falsificationism, Feyerabend insists that, "Lakatos offers words which 
sound like the element of a methodology. He does not offer a methodology" (EMEDOLU \& ONUOHA 2007, 58-59). Feyerabend enmeshes himself in what he calls the anarchistic method, and wrote the text Against Method to elaborate his view. As it stands, any unbridled quest for an absolute method in science is a mirage. In talking about method, at the moment, we do not wish to discuss styles of theoretical reasoning in science, which are principally inductive and hypothetico-deductive. Some other (not too principal or strategic) ones are the historical, postulational, evolutionary and axiomatic styles of reasoning. Meanwhile, what we desire to do, at the moment, is to take methodology back to its pristine tonality in the wake of modernity - which Lakatos made allusions to when he earlier mentioned seventeenth and eighteenth century. The crux of method at the natality (birth) of modern empirical science is nothing but experimentation. In that destitute time we heard such turn of phrase like "experimental philosophy". Even up to the time of Newton, he was still referred to as an "experimental philosopher". This shows that experiment was the fundamental method of science.

The pertinent question then becomes: Is there room for experimental method in African science? Of course, the answer to this is not farfetched; it is in the affirmative. I will illustrate my point hereunder with a true life story of a traditional herbalist/nature-man (or witchdoctor). He used to be my father's bosom friend. We used to run drug (herbal remedy) labels for him in our printing press where I was then serving the ritual or routine family apprenticeship. For what seemed a long while, the nature-man went underground only to resurface around the month of August in 1988. Contrary to his usual appearance or dermatological features, to be specific, his entire skin was covered with white patches. It appeared he was burnt, first degree. In his trepidation my father (the then Chief Executive Officer of Treasurer Press) asked what brought about the terrible condition. The nature-man's reply was clear, direct and shocking. He said: "I was trying out a little experiment on telekinesis, but committed a murderous error in the proportions of the required mixture; so the gun-powder threw me out of the cauldron (metallic barrel) in place of transmuting me into a living darting fire or meteorite". The very English phrase, "little experiment" (which the nature-man applied exactly in its anglicized form), baffled and haunted me for years. Can any experiment (failed or successful) which endangers human life be so aptly described as little? Does that blunder or suicidal act the witchdoctor performed fit into the scheme of experimentation? It does perfectly fit into it. Besides, Chimakonam contrives some brilliant experimental scenarios in his text [Introducing African Science].

What then is experiment, it origins, traditions and elements? Simply put, experiment is an empirical or mental process that deals with a controlled juxtaposing Oof some variables with the specific aim of arriving at some conjectured or Nunanticipated results or effects. Instruments are often used to achieve these effects. ס્Therefore, creation of effects or phenomena lies at the very centre of every -experimental investigation (as Ian Hacking tells us in the second part of his Representing and Intervening). It is in this connection that Pierre M. Duhem defines 
experiment in physics as the production of “...a physical phenomenon under conditions such that it may be observed exactly and minutely by means of appropriate instruments" (EMEDOLU 2014, 10). For his part, Max Plank says: "An experiment is a question which science poses to Nature, and a measurement is the recording of Nature's answer" (EMEDOLU 2014, 14).

Regarding the origins of experiment, any specific date cannot be fixed. Precisely as that which belongs to the technological tradition, its remotest origins could be traced to the moment when the cave men began to make or fashion out tools. As the fashioning of tools became more complicated, the molding of utility instrument reached some levels of sophistication. With attainment of some levels of sophistication of useful instruments man began to gather up the possibility of trying out this or that instrumental arrangement to yield more luxurious and phenomenal results. No doubt, simple observation of nature and chance-discovery were the pristine or underlying sparks that first galvanized mankind into scientific and technological search.

Generally speaking, when we talk about experiment we tend to include a whole lot of things. Indeed, experiment is not that which is restricted to a standardized laboratory confinement - a tradition we now refer to as analytic. As is well known, there is another tradition that is called mimetic or field experiment, wherein complete laboratory control techniques and artifization are not totally utilized. Yet, again, there is a third tradition which I have dubbed in my doctoral dissertation as the kitchen tradition, wherein mere fiddling around with thoughts, tools, instruments and material goods might lead to some intriguing results. Henceforth, the actual notion of experiment is broader than the stuff presented by the advocates of the analytic tradition of experiment (EMEDOLU 2007, 16-17).

Coming to another dimension of method, it is very important not to gloss over the fact that African science is said to be laden with spiritism and religious mythological entities that must be engaged through invocation. Often times, conjuration, incantation, charm, mesmerism and charlatanry are the choicest camp fellows of African science. Our advocacy at the moment though is to decharlatanize African science by specifically stripping it of conjurational words or spells and putting it upon the fast track of pure empirical stronghold. Nevertheless, a key member of the mock doctoral viva panel raised a very strong objection to this sort of reformative approach and insisted, incidentally, that it is the conjurational/incantatory words that mark out the uniqueness of African witchcraft/magic. Such a position can be supported by Ludwig Wittgenstein who argues that, "Magic always rests on the idea of symbolism and of language" (COOK 1983, 4). I do not doubt the prominent role of symbolism in sympathetic and contagious magic, for in both forms of magic there is this "...undying belief in a sympathetic interdependence of all parts of the universe" (TILLICH 1954, 44). In Eany case, I deeply contest the claim that magic must achieve its result only by Zresorting to language or spell, as if every form of magic is sorcery. Even though the sorcerer cannot part with magical spells, other magicians can maneuver and exploit 
events just with their craft and technical skills. Undoubtedly, it might even be later discovered that some of these charged words or sounds do actually possess some vibration effects and efficacy. By some future time such words or sounds might begin to constitute interesting studies in the field of mechanics. Even though we should keep our minds open to such a possibility, I do not wish to concern myself with such matters in this current enterprise; for we need to count 1 before 2 in this newly suggested shift of paradigm. Ernst Cassirer, in [Language and Myth], rather believes that, "It was a long evolutionary course which the human mind had to traverse, to pass from the belief in a physico-magical power comprised in the Word to a realization of its spiritual power" $(1946,61)$. Beyond the spiritual power of Word or language over the human soul, I still maintain that such powers of the spoken of Word might someday be taken in by the physico-mathematical sciences which earlier dumped the Word aspect of magic for want of instrumental connectivity. I do possess this felicitous hope precisely because I have personally experienced the physical powers of occult Egyptian words/spells. My late maternal aunt also had once told me of my own father's physical exploits with occult incantatory words. Evidence of this abound because it is a "reality lived" within the African continent. Now, Western Robotic technology has got to the threshold of inventing instruments that obey Word command, but time is not ripe for us to integrate Word into the method of our envisaged new African experimental science. No doubt, revolution in science is perpetual, and a subsequent call or phase of paradigm shift might take care of Word as an integral part of experimentation in African science. Be that as it may, what should fascinate us most is that good methods yield good results. What ensures this good method is that known entities are manipulated using basic or sophisticated scientific instruments.

\section{On Transmutation of Theoretical Entities in African Magic}

The popular goal of every scientific enterprise is theoretical explanation. But the African magical tradition has not agreeably fared better in this direction. Any explanations found in the forms of African magic can never be considered as part of the paraphernalia of a clean logic of justification in modern empirical science. Yet magic, in most of its forms, clearly play some vital role in the logic of discovery. Henceforth, for one to say that magic does not play any intrinsic (intensive) or extrinsic (extensive) role in modern scientific knowledge is to be blinded by a false scientific ideology, which we may conveniently call empirical justificationism - an impression created always in the bookish science of our time. But one wondrous fact is that modern empirical science (scientia media - in the sense of being physicomathematical) has not only placed much emphasis on theory but has almost transmuted theory into a complex edifice of un-observable entities. The Neo-

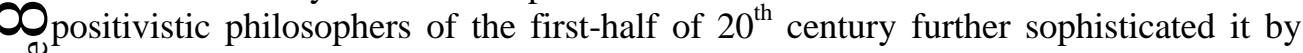
offocusing more on the logical structure of theories over against the contents or real nature of scientific theories. This sort of orientation (or too much logicization of science) leads to unwitting disbelief in the power of theories to explain reality. Of 
course, theories could be accepted in the Logical positivistic dispensation as instruments for prediction, or some lofty attempts at describing the world. Say what Western thinkers may, we must state that the logical structure of any scientific theory cannot be an intrinsic criterion for demarcating between scientific knowledge and other forms of life or belief systems.

Given the fact that western scientific theories are much too stylized and somewhat complex for any emergent African science to begin now to approximate, we must first begin to put certain things in place. We must begin to identify possible manipulable theoretical entities. Harré, in [Varieties of Realism: A Rationale for the Natural Sciences], categorizes entities used in theoretical explanations into three realms: $1,2 \& 3$. Realm 1 entities are purely observable entities. Realm 2 entities are un-observable, but can be observed through the use of experimental instruments. Finally, realm 3 entities are also unobservable, yet the effects can be somewhat detected by using some advanced or more sophisticated instruments. Over against the submission of logical positivism and constructive empiricism, observable entities of realm 1 theories are of little significance in Western science. Much importance is attached to entities of realms $2 \& 3$ theories. Typical entities of realm 2 theories are atoms, electrons, photons, positrons, bacteria, and so on. Prototypical realm 3 entity was virus before it was brought into the observable region through the fabrication of a more sophisticated high resolution electron microscope, and thereafter pushed into realm 2. The current discovery of Higgs (God) particle is leading contemporary science unto the supersonic highway of unimaginable and statistical inanities, which could be funneled into a new category of realm 4 theory.

In African science, both observable and unobservable entities are of equal importance. One major difference between unobservable entities in the West and Africa is located in the very character of entities postulated. The animistic or anthropomorphic worldview (weltanschauung) of the African makes him give credence to spirit entities as the very unobservable denizens (or entities) responsible for certain phenomena or effects we witness in scientific or technological practices. At this point I must use a familiar example to further illustrate my case. The mobile tracking technology of the West may award it to photons as the unobservable entities responsible for tracking down missing vehicles or other items. In Africa I have witnessed a crude simulacrum of mobile tracking technology, wherein a witchdoctor tracked a stolen church bell to Ariaria International Market - to the very point it was displayed for sale. In the theoretical explanation of this African event, credit can never be given to photons (carriers of electromagnetic waves), but to some spirit entities like amadioha (god of thunder) and ala (Earth goddess). At any rate, this orientation does not come as a surprise, precisely because Africa is enmeshed in $\mathrm{V}_{\text {some kind of transcendental spiritism. Even certain common illness like chicken pox }}$ $\infty_{\text {was once attributed to the menacing haunt of a monstrous old woman. To a noble or }}$ adhoroughgoing scientific mind that is a scandalous myth. This sort of myth is bandied $\sim$ around in traditional African society as a form of explanatory hypothesis. 
Chimakonam makes a brilliant ontological excursus into the nature of entities that inhabit or occupy the African universe. He maintains that there are "three different entities in the universe, such entities as matter, anti-matter and non-matter" $\left(2012^{\mathrm{b}}, 35\right)$. But it is not just enough for us to enunciate our own worldviews. Our Western counterparts have long mastered how to manipulate the anti-matter to such an extent that they can now tell us (in nuclear physics terms) that a drop of antimatter can electrify the entire city of New York. In point of fact, what we need now is a renewal of mind, so to approach science and technology in an objective manner. With such an objective orientation we will begin to witness standard or better or enough theories in our scientific enterprise that will provide cogent phenomenal clues as to how we can experimentally manipulate entities to positive effects; and by so-doing we can rehabilitate and facilitate our crude technology. This is no less a clarion call also for paradigm shift on the level of ontology.

\section{Conclusion}

We must conclude this paper by way of exhortation. European science emerged from a magical tradition. It is necessary that we use that historic event as a model to create a new African experimental science from our own natural magical tradition that is almost going bankrupt. That magnificent Euro-scenario of Modern Empirical Science standing in exchange for Magic can be given a broad brush painting again. Francis Bacon as a premier modern advocate of experimentalism (or experimental method of science) clearly saw that magic or witchcraft can help to advance science greatly. So, "Bacon tried to rehabilitate magic as natural science in its operative aspect in $D e$ Augmentis Scientiarum" (MARET 1965, 245). Therein Bacon also alluded to how King James I changed his mind in 1622 after legislating in 1604 that those charged or accused of practicing witchcraft must be executed. Sequel to the change of heart, some noble magicians plied their trade without molestation in the full glare of witnesses in England. But by that time they were branded "experimental philosophers", not magicians anymore. The most intriguing tale, at the end of the day, is that one author John Henry characterizes Isaac Newton as the last of these modern magicians when he writes:

Newton's interest in alchemy, his development of Neoplatonic concepts of spirit (as a possible cause of gravitational and electrical phenomena), his defence of occult qualities in natural philosophy and his belief in mathematical 'harmonies' (as a means of discovering the precise nature of God's creation) have all been recognized as indicative of the profound influence of magical traditions on his creative scientific work. For earlier historians this means that Newton must be seen as a 'Great Amphibium' who spanned 'two worlds'. 'With one foot in the middle ages and one foot treading a path of modern science', he was 'not the first of the age of reason' but 'the last of the magicians'. $(1990,594)$

This is not to give any impression that the modern Revolution in science began and ended in England. There were pockets of other scientific movements in other nations 
of Europe. Our fundamental aim in the glossy picture painted above simply translates it as an animating means for lacerating or blazing the minds of African scholars and academics. Henceforth, African scholars must all begin to think of cutting-edge refinement for African science. It is not enough to discredit or dismiss African scientific practices or procedures as merely diabolic, and suitable within the confederacy of charlatans and exploitative dare-devils. I dare say that, to remain within the enclave of the form of belief that perceives Africa as a worthless land is to infect ourselves with the scourge of oblivity or hollowness of mind that quickly reduces us to intellectual midgets. There is no shame in being this apologetic! No shame in tapping into the wisdom we already possess! For even Pope Paul VI, in Populorum Progressio, expresses faith in the capacity of every nation to contribute to world civilization when he categorically declares:

'The future of the world stands in peril,' the Council gravely affirms, 'unless wiser people are forthcoming'. And it adds: 'many nations, poorer in economic goods, are quite rich in wisdom and able to offer noteworthy advantages to others'. Rich or poor, each country possesses a civilization handed down by their ancestors. (part I, sec. 3, art. 40)

Having come thus far, I would finally suggest that Chimakonam's "...two rival schools in African science namely, the transcendentalist and the mechanist" $\left(2012^{\mathrm{b}}\right.$, 92) should try and play a complementary role to each other. Whatever useful idea we can get from anywhere in the process of consolidating African experimental science is somewhat acceptable; for as Chimakonam says, “... part essence of this advocacy ... is to bring African science up to speed by adopting and adapting some of the obvious giant strides in Western science" $\left(2012^{\mathrm{b}}, 94\right)$. The growth of African science must remain our guiding principle.

\section{Relevant Literature}

1. AQUINAS, Thomas. [Summa Theologiae, T. Mcdermott Ed.], 1989. Eyre and Spottiswoode: London. Web

2. ARISTOTLE. [Metaphysics (The Basic Works of Aristotle, Richard Mckeon, Ed.)], pp. 680-926, 2001. Modern Library: New York. Paperback 
Filosofia Theoretica: Journal of African Philosophy, Culture and Religions

3. KANT, Immanuel. [Prolegomena to Every Future Metaphysics (The Metaphysics of Kant, Carl J. Friedrich Ed.)], 1977. Modern Library: New York. Paperback

4. BAUDISCH, O. "Magic and Science of Natural Healing Waters", [Journal of Chemical Education], Vol 16. No. 9. Pp. 440-448, 1939. Web

5. BERNAL, Martin. [Black Athena: The Afro-Asiatic Roots of Classical Civilization. Vol. I, The Fabrication of Ancient Greece 1785-1985], 1991. Vintage: London. Paperback

6. CASSIRER, Ernst. [Language and Myth], 1946. Dover Publications Inc.: New York. Paperback

7. CASTELL, A., BORCHERT, D. M. \& ZUCKER, A. [An Introduction to Modern Philosophy], 1994. Macmillan College Pub. Co. Inc.: New York. Paperback

8. CHIMAKONAM, O. Jonathan. "Towards a Theory of African Science: Methods and Justification", [IOSR Journal of Pharmacy and Biological Sciences]], Vol. 3. No 1. Pp. 33-41, 2012. Web

9. _ _ [Introducing African Science: Systematic and Philosophical Approach], 2012. Authorhouse: Bloomington.Web

10. COHEN, N. [Biotechnology: Laboratory to Market Place, Vol. I], 1986. The Open University: Milton Keynes. Paperback

11. COHEN, Morris \& NAGEL, Ernest, "The Limits and Values of Scientific Method", [Philosophy and Contemporary Issues, J. B. Burr and Milton Goldinger Eds.], pp. 480-483, 1992. Macmillan Publishing Company: New York. Paperback

12. COOK, J. W. "Magic, Witchcraft, and Science", [Philosophical Investigations], Vol. 6. No. 1. Pp. 1-35, 1983. Web

13. EMEDOLU, Christian. "Ian Hacking on Experimentation and Scientific Realism: Critique", [Unpublished Ph.D Thesis], 2007. University of Port Harcourt. Paperback

14. ___ "The Onslaught of Antirealism in the Modern Period of Science: A Philosophical Excursus", [Kiabara: Journal of Humanities], Vol.15. No.1. Pp. 63-74, 2009. Paperback 
15. [Originality: Some Reflections on Authentic Development in Africa, Vol. 2], 2010. University of Port Harcourt Press: Port Harcourt.

16. "A Plea for Transformation in African Science", [Paved Routes of Modern Empirical Science: Critical Essays and Discussions in the History and Philosophy of Science, Christian Emedolu Ed.], pp. 235-242, 2013. Rex Press: Aba. Paperback

17. . [A Concise History of Scientific Experiment], 2014. Rex Press: Aba. Paperback

18. EMEDOLU, Christian \& ONUOHA, O. Jude. [Concept of Science as an Ideology: Silhouette of the Anarchist], 2007. University of Port Harcourt Press: Port Harcourt. Paperback

19. FEYERABEND, Paul. [Against Method], 1978. Verso: London. Paperback

20. __ .How to Defend Society Against Science" [Scientific Revolutions, Ian Hacking Ed.], pp. 156-167, 1981. Oxford University Press: Oxford. Paperback

21. FRAZER, G. James. [The Golden Bough: A Study of Magic and Religion], 1993. Wordsworth Editions Limited: Hertfordshire. Paperback

22. HACKING, Ian. [Representing and Intervening: Introductory Topics in the Philosophy of Natural Science], 1983. Cambridge University Press: Cambridge. Paperback

23. HALSTEAD, Beverly. "Scientific Method: Percept and Practice", [Second Order: An African Journal of Philosophy], Vol. 3. No 1. (Jan. 1974), pp. 2946. Paperback

24. HARRÉ, Rom. [Great Scientific Experiments], 1981. Oxford University Press: Oxford. Paperback

25. __. [The Philosophies of Science. $2^{\text {nd }}$ Edn.], 1984. Oxford University Press: Oxford. Paperback

26. _ [Varieties of Realism: A Rationale for the Natural Sciences], 1986. Basil Blackwell: Oxford. Paperback 
Filosofia Theoretica: Journal of African Philosophy, Culture and Religions

27. HENRY, John. "Magic and Science in the Sixteenth and Seventeenth Centuries", [Companion to the History of Modern Science, R. C. Olby, G. N. Cantor, J. R. R. Chistie \& M. J. S. Hodge Eds.], pp. 583-596, 1996. Routledge: London. Paperback

28. ___ "Magic and the Origins of Modern Science". [The Lancet], Vol. 354. Issue Supp- S4. P. 1, 1999. Web

29. JAMES, G. M. George. [Stolen Legacy], 1954. Philosophical Library: New York. Paperback

30. LAKATOS, Imre. [The Methodology of Scientific Research Programme: Philosophical Papers. Vol. I, John Worrall \& Gregory Currie Eds.], 1980. Cambridge University Press: Cambridge. Paperback

31. __ .History of Science and Its Rational Reconstructions", [Scientific Revolutions, Ian Hacking Ed.], pp. 107-127, 1981. Oxford University Press: Oxford. Paperback

32. MARET, R. R. "Magic", [Encyclopaedia of Religion and Ethics. Vol. 8, James Haztong Ed.], N.P., 1965. Scribner and Sons: New York. Web

33. MARKS, John. [Science and the Making of the Modern World], 1983. Heinemann: Oxford. Paperback

34. MCNEILL, J. T. "Magic and Infant Science". The Journal of Religion. Vol. 15. No. 3. Pp. 342-344, 1935. Web

35. NWALA, T. U. "Summary Discourse on the Debate Concerning the Existence, Nature and Scope of African Philosophy (1970-90)", [Critical Review of the Great Debate on African Philosophy (1970-1990), T. U. Nwala Ed.], pp. 1-60, 1992. William Amo Centre for African Philosophy: Nsukka. Paperback

36. NWIGWE, E. Boniface \& EMEDOLU, Christian. [Emergent and Contentious Issues in African Philosophy: The Debate Revisited], 2004. University of Port Harcourt Press.

37. OKERE, T. I. [African Philosophy: A Historico-Hermeneutical Investigation of the Conditions of its Possibility], 1983. University of America Press: Lanham. Paperback 
38. .(ed.). [Philosophy, Culture and Society in Africa], 2005. Afro-Orbis Publications Ltd.: Nsukka. Paperback

39. OPATA, Damian. "On What is African", [Critical Review of the Great Debate on African Philosophy (1970-1990), T. U. Nwala Ed.], pp. 61-80, 1992. William Amo Centre for African Philosophy: Nsukka. Paperback

40. ORUKA, Odera. "The Fundamental Principles in the Question of African Philosophy". [Second Order: An African Journal of Philosophy], Vol. 4. No 1. (Jan. 1975), pp. 29-46. Paperback

41. OZUMBA, O. Godfrey. "Analytic and Synthetic Dimensions of African Science”. [Sophia: An African Journal of Philosophy], Vol 2. No 1. Pp. 1926, 2000. Paperback

42. PAUL VI, Pope. [Populorum Progressio], N.P. Papal Encyclical: Vatican. Web

43. POPPER, R. Karl. [Objective Knowledge: An Evolutionary Approach], 1972. Clarendon Press: Oxford. Paperback

44. SHAPERE, Dudley. "Meaning and Scientific Change", [Scientific Revolutions, Ian Hacking Ed.], pp. 28-59, 1981. Oxford University Press: Oxford. Paperback

45. STRASSBERG, B. A. "Magic, Religion, Science, Technology, and Ethics in the Postmodern World", [Zygon], Vol. 40. No. 2. Pp. 307-322, 2005. Web

46. TILLICH, P. "The Relation of Religion and Health: Religions, Magic, and Natural Healing Distinguished", [Pastoral Psychology], Vol. 5. No. 4. Pp. 41-52, 1954. Web

47. UDUMA, O. Uduma. "The Question of the 'African' in African Philosophy: In Search of a Criterion for the Africanness of a Philosophy", [Filosofia Theoretica: Journal of African Philosophy, Culture and Religions], Vol. 3. No 1. Pp. 127-146, 2014. Web

48. WIENER, M. J. "Magic Worlds Through Religion, Science and Magic". [Anthropological News], Vol. 45. No. 8. Pp. 10-11, 2004. Web

49. WHITEHEAD, A. N. [Science and the Modern World], 1948. Mentor Books: New York. Paperback 